\title{
Stable Peace
}


This page intentionally left blank. 
Sponsored by the Lyndon B. Jobnson School of Public Affairs 



\section{Stable Peace \\ Kenneth E. Boulding}

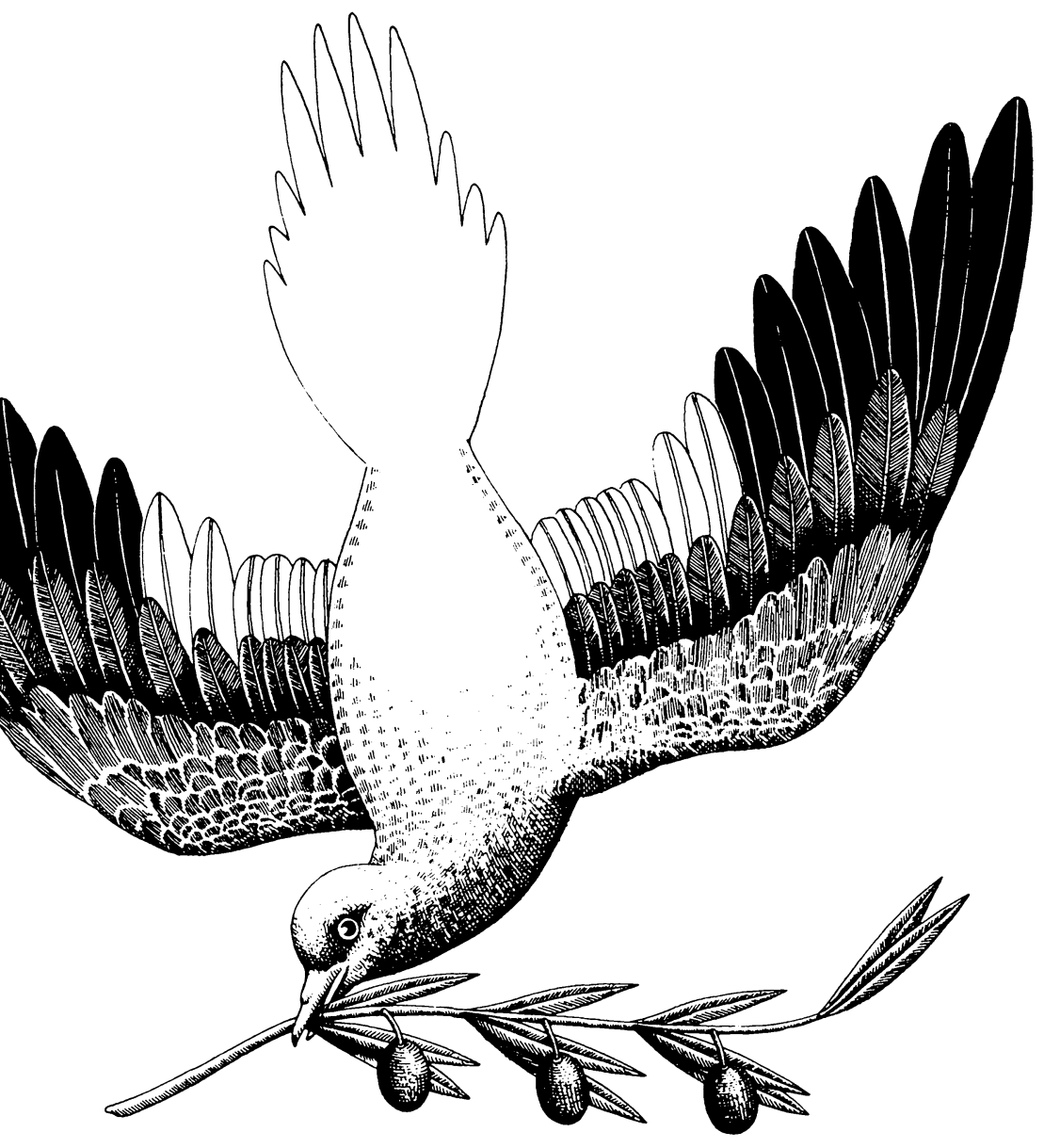

University of Texas Press, Austin 
Library of Congress Cataloging in Publication Data

Boulding, Kenneth Ewart, 1910-

Stable peace.

1. Peace-Research. 2. International relations-Research. I. Title.

JXI904.5.B69 327'.172'072 78-617

ISBN 978-0-292-76448-4, pbk.

ISBN 978-I-4773-0570-6, library e-book

ISBN 978-I-4773-057I-3, individual e-book

Copyright (C I 978 by the University of Texas Press

All rights reserved

Printed in the United States of America

Set in Garamond Light by G \& S Typesetters Inc.

Illustration by Ed Lindlof

Design by Richard Hendel

Requests for permission to reproduce material from this work should be sent to:

Permissions

University of Texas Press

P.O. Box 7819

Austin, TX 78713-7819

http://utpress.utexas.edu/index.php/rp-form 